Article

\title{
Environmental Literacy Level Comparison of Undergraduates in the Conventional and ODLs Universities in Sri Lanka
}

\author{
Janaka Kuruppuarachchi $^{1, *}$, Vineetha Sayakkarage ${ }^{2}$ and Buddhika Madurapperuma ${ }^{3}$ \\ 1 Department of Botany, The Open University of Sri Lanka, Nawala 10250, Sri Lanka \\ 2 Kandy Regional Center, The Open University of Sri Lanka, Kandy 20000, Sri Lanka; \\ svineetha2006@gmail.com \\ 3 Department of Environmental Science \& Management, Humboldt State University, Arcata, CA 95521, USA; \\ bdm280@humboldt.edu \\ * Correspondence: kajmkuruppu@gmail.com; Tel.: +94-071-801-1982
}

Citation: Kuruppuarachchi, J.;

Sayakkarage, V.; Madurapperuma, B.

Environmental Literacy Level

Comparison of Undergraduates in

the Conventional and ODLs

Universities in Sri Lanka.

Sustainability 2021, 13, 1056.

https://doi.org/10.3390/su13031056

Academic Editor: Marc A. Rosen

Received: 25 November 2020

Accepted: 30 December 2020

Published: 20 January 2021

Publisher's Note: MDPI stays neutral with regard to jurisdictional claims in published maps and institutional affiliations.

Copyright: (c) 2021 by the authors. Licensee MDPI, Basel, Switzerland. This article is an open access article distributed under the terms and conditions of the Creative Commons Attribution (CC BY) license (https:// creativecommons.org/licenses/by/ $4.0 /)$.

\begin{abstract}
Developing positive attitudes by upgrading the environmental literacy level is very important to protect nature from anthropogenic pressures. This study evaluates existing knowledge, awareness, attitude and behavior, perceived issues, and solutions of undergraduates on major environmental issues of two national universities with different teaching methods of the Open University of Sri Lanka (OUSL: open distance learning) and the University of Peradeniya (UP: conventional). A questionnaire survey (29 structured and 04 open-ended items) was adapted with 800 undergraduates of engineering, science, management, law, and arts / social sciences disciplines. We computerized descriptive statistics, such as frequency and cross-tabulation, and mean comparison using the SPSS software. The results showed that there was no significant difference $(p>0.05)$ of existing environmental knowledge in undergraduates of two universities. However, there was a significant difference in undergraduates' family income $(\mathrm{F}=5.387, p<0.001)$ and family educational background $(p<0.05)$ with environmental knowledge. School education played a main role in building environmental concepts for undergraduates. The environmental attitude and behavior of both student groups showed a fairly favorable status. The majority of respondents suggested that TV and radio were the most effective media for environmental awareness. Undergraduates of the OUSL and UP were more interested in "tree planting" / "gardening" (22.7\%) and "hiking (mountain climbing)" (25.7\%), respectively. Both OUSL and UP groups recognized "global warming" as the major global environmental issue and air pollution as the local issue. This study highlights the importance of building environmental knowledge among undergraduates, mainly on global and local environmental issues, to improve sustainable environment management.
\end{abstract}

Keywords: questionnaire survey; environmental literacy; undergraduates; Sri Lanka

\section{Introduction}

Rapid industrialization, urbanization, and over-exploitation of natural resources have caused huge environmental degradation and an imbalance among components of the biosphere such that maintenance of the modern lifestyle of the human is inviable. Harmful waste secretions, climate change, ozone layer depletion, acid rains, and eutrophication are a few familiar environmental catastrophes [1]. Such global issues will vary between regions, causing diverse impacts on agriculture, forestry, human health, and biodiversity, and these are all very severe when manifested as local problems [2]. Globally, natural systems, such as coral reefs, mangroves, tropical, temperate, and boreal ecosystems, are at the risk of irreversible damages [3]. Such pieces of evidence indicate that Homo sapiens is the most dangerous and self-centered animal in the world who is now endangered, and will receive negative feedback from nature in the near future. So, humans are formulating different types of environmental conservation strategies for their survival. Until a human understands their real position and role in a cyclical biosphere, the world is at risk. 
The change of the human mind and developing a positive attitude toward the environment is an effective way to conserve nature. Increasing environmental literacy in every stage of life will lead to a change in attitude and resulting behaviors or actions of an individual, which will ultimately protect the entire world. It is important to determine what people know, how they feel, and what actions are required to protect the environment [4].

Environmental education (EE) is a process that allows individuals [5] and communities, and organizations [6,7] to learn and explore the environment and its issues, engage in problem-solving, and take action to improve the environment to address global or local challenges. According to Meredith [8], EE is the ability to emotionally understand the natural laws, all the changes, cause-and-effect relationships between the quality of the environment, and human behavior. The person's environmental literacy is parallel to individual perception, knowledge, awareness, and attitude towards environmental issues. So, increasing environmental literacy will lead to a change in the behavior or action of a person. Hence, the recognition of existing knowledge in different sectors of the environment is very important to make conservation strategies for the environment. Most of the former studies have mainly paid attention to the quantification of environmental literacy of school students and the public, lacking study at the university level [4,9-14]. Very few studies have been carried out on environmental education and the urgent need to conserve this biodiversity hotspot in tropical Asia through awareness of Sri Lankan folk [15].

Examining the existing environmental knowledge of university students, who are future policymakers, is very important. Such examinations are mostly carried out by surveying techniques with help of structured types of questionnaires $[4,9-11,16]$. There are diverse aspects of the environment and its effects, such as purchase intention on greener products [17], the effect of materialism on environment knowledge [18], perception of exceptional risks [19], impact on climate change [20], and the perception of awareness, attitude, and knowledge of the environment [21]. Gulgun et al. [9] recognized public awareness as the key factor of sustainable environmental protection and explained the importance of environmental education starting from nursery school levels.

A lack of awareness was the leading factor for environmental problems in Bangladesh [16] and therefore public awareness and education were recommended to mitigate the negative impact on the environment. Contreras, [22] highlighted the importance of integrated approaches in upgrading the literacy level of university students. Selvam and Nazar [10] recommended integrating approaches with government, private, and non-government sectors to make university students aware of environment and disaster management. Aminrad et al. [23] recommended coordinating knowledge, attitude, and behavior of students. Misfud [24] suggested the importance of linking the ecological knowledge of students with social concepts.

Liu and Lin [11] have investigated the undergraduates' ideas about nature and humannature relationships and to find whether students show pro-ecological behavior; the ideas of students about nature and human-nature relationships often seemed to be a mixture of worldview tendencies. The findings of Veisi et al. [25] indicated that university students had a positive attitude, a high degree of concern, and showed sensitivity to the environment, but that they had only low-to-moderate levels of knowledge. The study explores how gender, age, and the environmental experience had a significant effect on environmental literacy, and how mass media served as the main source of environmental information. Similarly, Teksoz et al. [26] demonstrated that environmental knowledge was highly correlated with attitude and responsibilities when undergraduates were involved in outdoor activities. Finally, to upgrade the environmental literature level of university students, it is highly recommended to include environment-related course units in any degree program [27].

Universities are the foundations that educate people who will be community leaders and managers in the future world [28]. To make the world successful, future leaders must pay attention to corporate social responsibilities including high environmental literacy and a positive attitude toward nature. There is a lack of studies carried out to quantify the environmental literacy level of students of higher education institutions [29,30]. 
Examining the existing knowledge, attitudes, and positive involvement in environmental conservation in undergraduates is very important for future sustainability [31]. Thus, the findings of this study would provide strong evidence for policymakers to plan environment-friendly strategies in the higher education sector. This study aims to explore existing environmental knowledge, awareness, attitude, behavior, and perceived suggestions regarding major environmental issues by university students of different disciplines within two different teaching methodologies.

\section{Materials and Methods}

\subsection{Population and the Sample}

This research was carried out at the Open University of Sri Lanka (OUSL) and the University of Peradeniya (UP) in 2018. The OUSL, the premier Open and Distance Learning (ODL), was established in 1980. Currently, more than 41,000 students (in 2020) are registered under 06 different faculties [32]. The UP is a seventy-seven-year-old conventional university in Kandy with a total of 12,697 undergraduates registered in nine faculties. Annual enrollment of approximately 2697 undergraduates in 2017/18 academics based on results of the G.C.E. (A/L) examination [33].

\subsection{Selection of Study Sample}

The purposive stratified random sampling technique was adapted to select the study sample [4]. The First population was stratified based on the availability of disciplines in both universities. Five comparable disciplines between the institutions were included in the study: engineering, science, management, law, arts, and social sciences. A total of 800 undergraduates (400 from each university) were selected randomly and distributed the piloted questionnaire for the survey [4,34-36]. The selected sample was represented by engineering (OUSL 26.5\%, UP 24\%), science (OUSL 19.8\%, UP 23.8\%), management (OUSL 15\%, UP 7.8\%), law (OUSL 23.8\%, UP 3\%), and social sciences (OUSL 15\%, UP 45\%) undergraduates. The sample size of this survey is higher than similar studies $[13,16,22,37]$.

\subsection{Structure of the Questionnaire}

The questionnaire included 29 items (Figure S1) in structured parts (A, B, C, D, and E) and an open-ended part (Part F with 04 main items). The first twelve items of part A assessed socioeconomic background, item 13 was designed to prioritize the interest in environmental activities, and item 14 was used to prioritize sources of acquired environmental knowledge of undergraduates. Knowledge of environmental issues was investigated in seven (07) items in part $B$, which was designed to prioritize global environmental issues. Items 16, 18, and 20 were multiple-choice questions (MCQs) to explore the existing environmental knowledge, while items 17,19 , and 21 were designed to prioritize the risks of each global environmental issue. Part C (items 22 to 24) was designed to explore attitudes towards the environment, including three (03) items in five-point Likert scale questions. Part D was designed to survey environmental behavior consisting of two (02) questions (items 25 and 26) in a five-point Likert scale. Part E regarded student's perceptions on present environmental protection efforts and policies which included three (03) multiple questions (Items 27-29) to obtain opinions on present environmental protection efforts and policies in Sri Lanka. Perceived answers for open-ended items were subject to quantification with frequency percentages.

\subsection{Data Analyses}

Data of the structured components were analyzed using the SPSS software. The mean, standard deviation, frequency, and cross-tabulation were calculated for the items 1 to 12. The statistical analyses, i.e., $t$-test, ANOVA, and Pearson's coefficient of correlation, were tested at 0.05 level of significance using the two-tailed test to find out the correlation between environmental knowledge and socioeconomic backgrounds [9,22]. 
The percentage of frequency of choice and the resulting priority was calculated for items 13,14,15,17, 19, and 21. To evaluate environmental knowledge, the percentage of correct answers for items 16, 18, and 20 per undergraduate was calculated. Quantification of attitude (items 22, 23, and 24) and behavioral level (items 25 and 26) was carried out by percentage of frequencies. The percentage of frequencies for items 27, 28, and 29 was calculated using the cross-tabulation techniques. The students' perceptions of environmental issues were analyzed using a word cloud analysis technique.

\section{Results}

The results are presented according to the objectives of the study under the following subtitles: recognize the socioeconomic background of the target group; identify the interest in environmental-related activities of the university students; recognize the source of acquired environmental information, existing knowledge and awareness levels on major environmental issues of students of the two universities and make comparison among factors; find out the attitudes and behavior of the university students' about the environment; find out reasons for the environmental issues in Sri Lanka and solutions perceived by the target group.

\subsection{Socioeconomic Background}

Items 1-12 of part A of the questionnaire are structured to detect the socioeconomic and demographic nature of the study sample. The majority of students in both universities below 30 years were females excluding law (40\%) of the OUSL (OUSL 62\%, UP 57.52\% except engineering of OUSL (43.6\%), UP (40.6\%)). Only the OUSL showed representative married or unemployed undergraduates in arts/social sciences (43.3\%, 66.7\%), law (33.7\%, $63.2 \%)$, management $(10 \%, 93.2 \%)$, engineering $(8.5 \%, 50 \%)$, and Science $(7.5 \%, 26.6 \%)$ respectively. The majority of engineering (50\%) and science (45.6\%) students of OUSL, and arts/social sciences (52.4\%) of UP, resided in village areas. Except for law (41.7\%) and arts/social sciences (38.6\%) of UP, other undergraduates studied (approximately 60\%) were from popular schools.

The majority of family members of engineering $(60.4 \%)$ and science $(57.9 \%)$ students of UP are graduates or higher, while engineering $(75 \%)$, and science $(70 \%)$ students of OUSL showed in majority to have less qualified family members. The family members of students within the management $(43.3 \%)$, law $(46.3 \%)$, and arts / social sciences $(41.7 \%)$ disciplines of OUSL showed higher educational status than their peers in UP as well as in other disciplines of the OUSL. The highest monthly family income category was shown by students of engineering (58.3\%) and science $(53.7 \%)$ of UP and management $(43.3 \%)$ and law (42.1\%) of the OUSL. Management (58.1\%), law (83.3\%), and arts/social sciences $(48.8 \%)$ of UP undergraduates were from the middle-income category. Students with a high educational background get more opportunities to enter professional fields in UP.

\subsection{Interest in Environmental Related Activities}

Recognition of a person's interest is very important in the awareness and education sector. Perceived answers recognized that "hiking" was the most interested activity of the UP undergraduates (25.7\%) and the least interested activity of the OUSL undergraduates (11.2\%). OUSL undergraduates $(22.7 \%)$ were most interested in "tree planting/gardening." However, UP undergraduates (16\%) placed said activity in fourth place, which would be because UP is surrounded by sufficient tree cover and vice versa for OUSL. Approximately equal percent of undergraduates in both universities were interested in "bird watching" (UP $17.7 \%$ and OUSL $16.5 \%$ respectively). In both universities, more than $94 \%$ of undergraduates were interested in any of the environmental-related activities. On the other hand, nearly $9 \%$ of engineering and $12 \%$ of science undergraduates of the UP and $11 \%$ of engineering, $4 \%$ of science, $5 \%$ of law and $7 \%$ of social sciences of OUSL undergraduates had no interest in any environmental activities. 


\subsection{Major Source of Information for Environmental Knowledge}

Undergraduates of UP (37.7\%) and undergraduates of OUSL (40.5\%) have recognized that "school education" is the main information provider of their environmental awareness (Figure 1). A total of $22.5 \%$ of undergraduates of the UP acquired their environmental knowledge from the printed media. Undergraduates of both universities (11\%) perceived "university" as a source of information given as 4th and 5th priority by undergraduates of UP and OUSL respectively. Very poor priority responses (5.2\% undergraduates of UP and $2.7 \%$ OUSL respectively) were given to the "friends or peers" as a source of information.
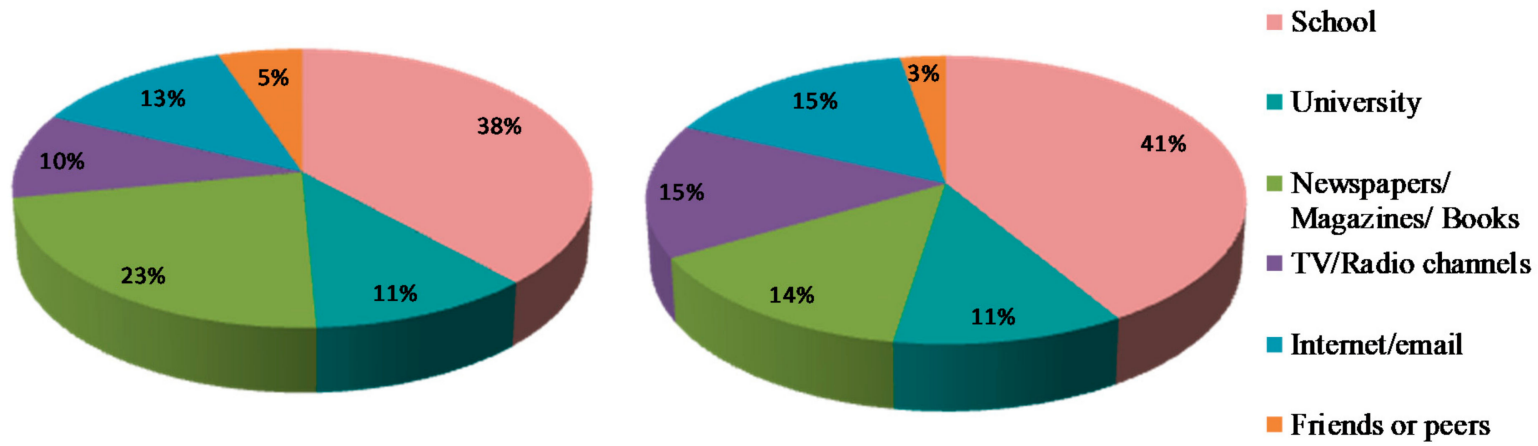

Figure 1. Source of information on the environmental knowledge of undergraduates in the UP (left) and OUSL (right).

\subsection{Diversity of Existing Environmental Knowledge among Different Disciplines}

Results of the one-way ANOVA showed in Figure 2. There was a significant difference between the mean percentages of environmental knowledge among all the discipline groups $(\mathrm{F}=9.453, p<0.05)$. The environment knowledge was high among Science $(37.34 \% \pm 1.63)$ and Law $(34.74 \% \pm 1.6)$ students of the OUSL and Science $(34.61 \% \pm 1.75)$ and Engineering $(31.9 \% \pm 63)$ of UP. Only $45.6 \%$ of undergraduates of both universities were scored with more than $30 \%$ of the mean percentage of knowledge on the environment.

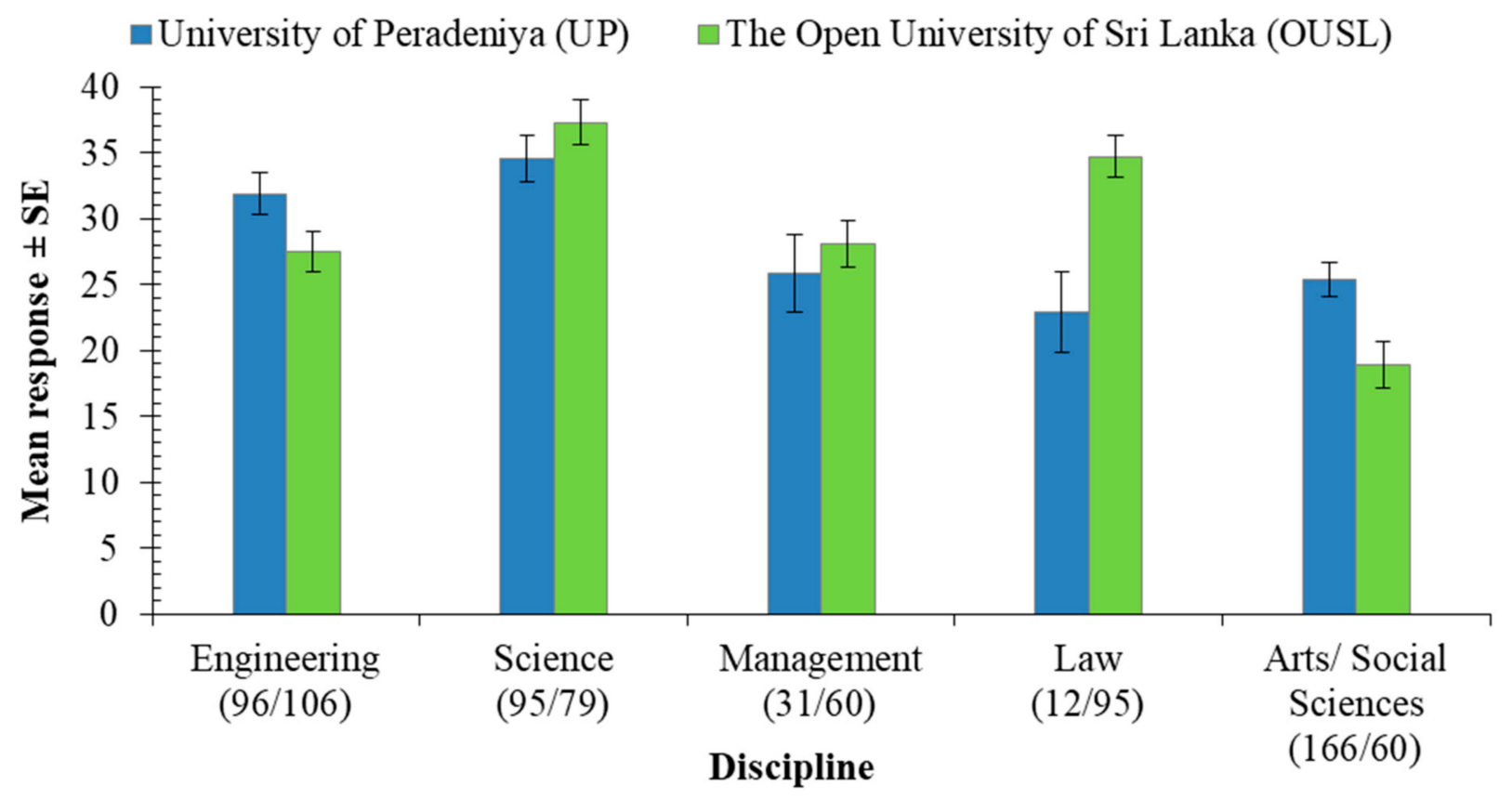

Figure 2. Different levels of knowledge of the environment. The total number of responses for each discipline in each campus (first UP and second OUSL respectively) is given in the parenthesis. 


\subsection{Comparison of Existing Level of Knowledge on Environment among Undergraduates}

Environmental knowledge between UP and OUSL was compared using an independent t-test. Results showed that there was no significant difference $(p>0.05)$ between undergraduates of UP and the OUSL on environmental knowledge. The mean \% frequency of the undergraduates of UP and OUSL was $29.1 \%$ and $30 \%$ respectively (Table 1 ). Our sample size is large $(800, n>30)$ and therefore the sampling distribution is close to a normal distribution. The t-test results showed that there was a significant difference between environmental knowledge and the education level of the family $(\mathrm{F}=2.64, p<0.05)$. The results revealed that the educational qualification of family members of undergraduates was positively correlated with environmental knowledge in students. Having a graduate or higher educated family member, G.C.E. (A/L), G.C.E. (O/L), and Lower than G.C.E. (O/L) showed the percentage mean of existing knowledge as $31.27 \pm 0.95,28.61 \pm 0.8,27.12 \pm 2.04$, and $24.31 \pm 3.98$, respectively, in the students. If the educational qualification of a family member is high, the environmental knowledge of the undergraduate increases accordingly.

Table 1. Comparison of level of existing environmental knowledge between two universities.

\begin{tabular}{|c|c|c|c|c|c|c|c|c|c|}
\hline University & $\mathbf{N}$ & Mean \% & $\mathbf{F}$ & Sig. & $\mathbf{t}$ & df & Sig. (2-Tailed) & Mean Difference & Std. Error Difference \\
\hline University of Peradeniya & \multirow{2}{*}{400} & 29.13 & \multirow{2}{*}{0.1} & \multirow{2}{*}{0.729} & 0.75 & 798 & 0.455 & -0.875 & 1.172 \\
\hline The Open University of Sri Lanka & & 30 & & & 0.75 & 796 & 0.455 & -0.875 & 1.172 \\
\hline
\end{tabular}

\subsection{Comparison of Existing Level of Environmental Knowledge with Family Income}

The environmental knowledge of the respondents significantly varied with their family income $(F=5.387, p<0.001)$. Students from the lowest income ( $<$ SLR 10,000.00/month) families showed lesser environmental knowledge $(23.21 \% \pm 3)$ than those with the highest monthly family income (SLR > 40,001) $(31.8 \% \pm 0.94)$. Results of this study highlighted that economic status and the education level of the family influence the student's knowledge of the environment (Table 2).

Table 2. Variation of environmental knowledge with family income.

\begin{tabular}{|c|c|c|c|c|c|c|c|c|}
\hline Monthly Family Income Rs. & $\mathbf{N}$ & Mean \% & Std. Deviation & Std. Error & df & Mean Square & $\mathbf{F}$ & Sig. \\
\hline$<10,000$ & 28 & 23.21 & 15.85 & 3.00 & 4 & 1447 & 5.387 & 0.000 \\
\hline $10,001-20,000$ & 46 & 32.88 & 14.28 & 2.11 & 795 & 9 & & \\
\hline $20,001-30,000$ & 124 & 30.85 & 17.27 & 1.55 & 799 & & & \\
\hline $30,001-40,000$ & 295 & 26.74 & 16.29 & 0.95 & & & & \\
\hline$>40,001$ & 307 & 31.84 & 16.45 & 0.94 & & & & \\
\hline
\end{tabular}

\subsection{Awareness of Different Local/Global Environmental Problems}

We analyzed the student's perception of environmental issues using a word cloud analysis. The frequency of words is represented by font size, with the most frequent words being the largest. The major environmental issues identified by students are deforestation, solid waste management, air/water pollution, global warming, and soil erosion (Figure 3). The main causes identified for these environmental consequences are unawareness, human activities, and loopholes in law and policy. Undergraduates of UP (52.2\%) and OUSL $(41.2 \%)$ have given their priority in the same order, with global environmental issues and perceived global warming as the most serious problems. Then, ozone layer depletion $(19 \%$ both UP and OUSL), loss of biodiversity (UP 15.2\%, OUSL16.5\%), acid rains (UP 2.7\%, OUSL 7.2\%), agricultural pollutants (UP 9.5\%, OUSL 10.2\%), and depletion of fossil fuels (UP $1.2 \%$, OUSL $4.2 \%$ ) were recognized as the next priorities. 


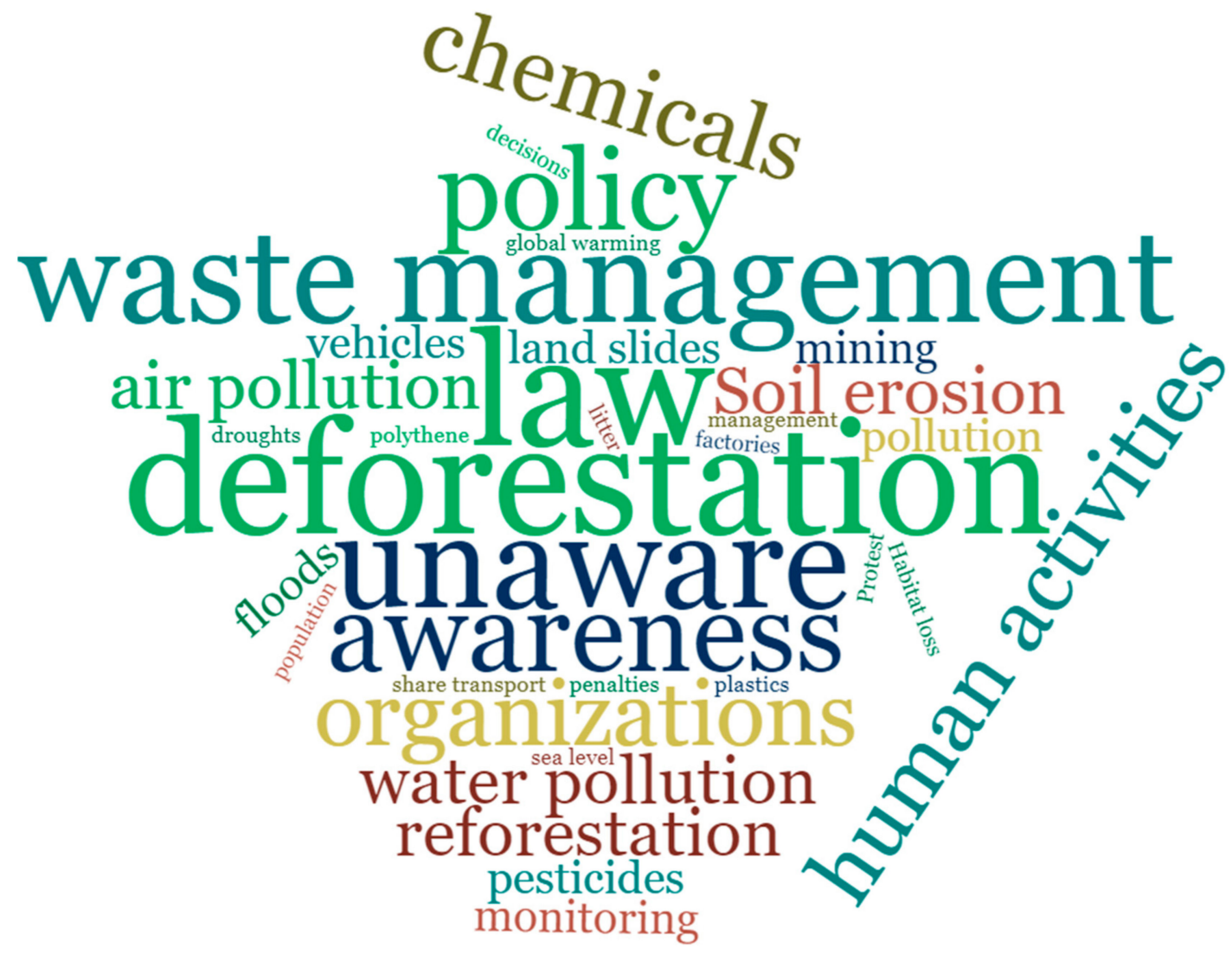

Figure 3. Student's perception of environmental issues such as problems, causes, suggestions, and sustainability in Sri Lanka.

\subsection{Awareness on Global Warming and Its Effects}

Part B, item 17 was designed to evaluate the effect of global warming. Most environmental global issues are interconnected and have effects at both the global scale and the regional level. Undergraduates of UP $(25.3 \%)$ perceived that the most serious effect of global warming was unbalanced natural ecosystems (Table 3). However, the perception of undergraduates of the OUSL (23.5\%) was recognized as sea level rising. The second most serious effect was the rising of sea level for UP students and unbalanced natural ecosystems for OUSL respondents. Both universities perceived the third highest risk as a change of global weather conditions (undergraduates of UP 18\% and OUSL 19.3\%).

Table 3. Perceived responses to the effects of global warming.

\begin{tabular}{ccc}
\hline Environmental Problem & $\begin{array}{c}\text { Undergraduates of } \\
\text { UP (\%) }\end{array}$ & $\begin{array}{c}\text { Undergraduates of } \\
\text { OUSL (\%) }\end{array}$ \\
\hline Endanger the balance of the natural ecosystems & 25.3 & 19.8 \\
Sea level rising & 21 & 23.5 \\
Ocean acidification & 6.8 & 12 \\
Species is at risk of extinction & 15.8 & 6.8 \\
Risk of extreme weather conditions & 18 & 19.3 \\
Melting of icecaps at the poles & 13.8 & 17.3 \\
\hline
\end{tabular}

\subsection{Awareness of Ozone Layer Depletion (OLD) and Its Effects}

Understanding among undergraduates of the effects of ozone layer depletion (OLD) was evaluated from Part B, item 19 of the questionnaire. Both respondents of UP (50.5\%) and OUSL (53.8\%) perceived an increase in skin cancer as the most serious issue due to the OLD. Undergraduates of UP (26\%) perceived that the second serious issue as suppression of the immune system and OUSL undergraduates (17.8\%) perceived the increase of eye 
cataracts as the second serious issue. They both perceived an increase of eye-burning as the least serious problem due to the OLD as UP (2\%) and OUSL (5.3\%) respectively.

\subsection{Awareness of Acid Rain and Its Effects}

Evaluation of the perceived knowledge of acid rain and its effects was arranged under Part B in item 21 of the questionnaire. Undergraduates of both universities prioritized acidification of lakes and streams and harm to aquatic ecosystems as the most serious effects (UP 27.8\%, OUSL 31\%), damage to flora / fauna as the second most serious risk (UP $22.5 \%$, OUSL $26.5 \%$ ), with degradation and harms the public health categorized as a third risk (UP 22\%, 15.8\% OUSL).

\subsection{The Attitude of the Undergraduates towards the Environment}

The importance of the statement "The present generation should ensure that the environment is maintained or enhanced for the benefit of future generations" was recognized through the survey. Undergraduates (UP 79.5\%, OUSL 75\%) perceived this statement with a high percentage of positive attitudes, responding "agree" or "strongly agreed" to the said statement. However, undergraduates of both universities disagreed or strongly disagreed (UP 75\%, OUSL 51.75\%) with the statement "Humans have the right to modify the environment to suit their needs". This implies that undergraduates of UP show a comparatively higher level of positive attitudes toward the environment than OUSL undergraduates. For the statement "Humans must live in harmony with nature to survive" both undergraduate groups show a good attitude, with $79.5 \%$ of UP and $75 \%$ OUSL undergraduates responding "agree" or "strongly agree". Although students exhibited favorable attitudes to the environment, our results show that there is a need for further improvement of environmental attitude because approximately more than $20 \%$ are on the unfavorable side.

\subsection{The Behavior of the Undergraduates toward the Environment}

Understanding pro-environmental concern and behavior is far more complex, as influences include personal and social factors or undetected combinations. Perceived behavior of students regarding the provided statement "I try my best to reduce waste in my daily life" indicates strong support by students in both universities (UP 71\%, OUSL 64\%). However, undergraduates (UP 20\%, OUSL 22\%) perceiving that they are neutral to the situation is questionable, both in attitude and behavior. The majority responses to the statement of "I report possible offenses of environmental regulations to authorities" were "neutral" (UP 37\%, OUSL33\%) and "act not" (UP 21\%, OUSL: 20\%). Of the undergraduates, $23 \%$ of UP responded as "never act on", while $25 \%$ of OUSL responded as "act on." A small portion of undergraduates responded as "always acting on" (UP 3\%, OUSL 9\%).

\subsection{Perceived Responses to the Most Viable Solutions for Environmental Issues in Sri Lanka}

Undergraduates of most disciplines, including engineering (39.6\%), science (35.8\%), and arts / social sciences (63.3\%) of UP, and science (51.9\%), and social sciences (38.3\%) of OUSL have recognized the most practical solution for solving environmental issues in Sri Lanka as "Education for raising the awareness of public" (Table 4). OUSL law undergraduates $(37.9 \%)$ have perceived that both "Education for raising the awareness of public" and "Legal regulations" were the best options. OUSL engineering students (38.7\%) have perceived "Technological improvements" as the best solution as consistent with their technological backgrounds. Undergraduates of management (UP 38.7\%, OUSL 43.3\%), and Law of UP (91.7\%) have perceived that "Legal regulations" were the best answer to solve environmental problems in Sri Lanka. Engineering groups of both universities (UP $26 \%$, OUSL $37.7 \%$ ) and science undergraduates (29.5\%) of UP have recognized their secondbest solution as "Legal regulations" while management students (33.3\%) of OUSL have recognized their second solution as "Education for raising the awareness of the public." 
Table 4. Perceived responses to the most viable solutions for environmental issues.

\begin{tabular}{ccccccc}
\hline University & Discipline & TI & ERAP & LR & UARMIP & MR \\
\hline & Engineering & 8.3 & 39.6 & 26 & 19.8 & 6.2 \\
Undergraduates of UP & Science & 3.2 & 35.8 & 29.5 & 14.7 & 16.8 \\
& Management & 16.1 & 9.7 & 38.7 & 22.6 & 12.9 \\
& Law & 0 & 0 & 91.7 & 8.3 & 0 \\
& Arts /Social Sciences & 7.8 & 63.3 & 28.9 & 0 & 0 \\
\hline \multirow{2}{*}{ Undergraduates of the OUSL } & Engineering & 38.7 & 17.9 & 37.7 & 5.7 & 0 \\
& Science & 10.1 & 51.9 & 13.9 & 17.7 & 6.3 \\
& Management & 6.7 & 33.3 & 43.3 & 13.3 & 3.3 \\
& Law & 13.7 & 37.9 & 37.9 & 8.4 & 2.1 \\
& Arts/Social Sciences & 16.7 & 38.3 & 18.3 & 15 & 11.7 \\
\hline
\end{tabular}

TI-Technological improvements; ERAP—Education for raising the awareness of the public; LR-Legal regulations; UARMIP_-Using alternating raw materials in industrial plants; MR-Monetary regulations (fine etc.).

\subsection{Perceived Solutions for Way to Attract Public Attention towards Environmental Issues in} Sri Lanka

As shown in Table 5, undergraduates of the various disciplines, engineering (50\%), science $(45.3 \%)$, and arts / social sciences (31.9\%) of UP and management (50\%), engineering $(35.8 \%)$, sciences $(39.2 \%)$, and social sciences $(33.3 \%)$ of the OUSL, have recognized that "TV- Radio" is the most effective activity to attract public attention towards environmental issues in Sri Lanka. Management undergraduates of UP (29\%) have perceived that both "Conference and seminar" and articles in "Newspapers, books, and magazines" were good approaches for the dissemination of knowledge on the environment. Law students of UP $(50 \%)$ selected "Newspaper, book and magazines" as the best approach, while OUSL Law students $(38.9 \%)$ perceived the best option as "Telephone/fax, the internet, and Email."

Table 5. The most effective activities used to attract public attention to environmental issues in Sri Lanka.

\begin{tabular}{|c|c|c|c|c|c|c|}
\hline University & Discipline & CS & NBM & TR & TFIE & CANGO \\
\hline \multirow{5}{*}{ Undergraduates of the UP } & Engineering & 9.4 & 6.2 & 50 & 7.3 & 27.1 \\
\hline & Science & 7.4 & 13.7 & 45.3 & 6.3 & 27.4 \\
\hline & Management & 29 & 29 & 16.1 & 12.9 & 12.9 \\
\hline & Law & 41.7 & 50 & 0 & 0 & 8.3 \\
\hline & Arts/Social Sciences & 19.9 & 26.5 & 31.9 & 0 & 21.7 \\
\hline \multirow{5}{*}{ Undergraduates of the OUSL } & Engineering & 21.7 & 19.8 & 35.8 & 22.6 & 0 \\
\hline & Science & 7.6 & 7.6 & 39.2 & 7.6 & 38 \\
\hline & Management & 3.3 & 11.7 & 50 & 8.3 & 26.7 \\
\hline & Law & 7.4 & 16.8 & 35.8 & 38.9 & 1.1 \\
\hline & Arts/Social Sciences & 18.3 & 15 & 33.3 & 8.3 & 25 \\
\hline
\end{tabular}

CS-Conference and seminars; NBM-Newspaper, book, and magazines; TR-TV-Radio; TFIE-Telephone/fax, internet, and email; CANGO-Campaigns/Activities of non-governmental organizations.

The OUSL adapted open distance learning (ODL) system includes printed materials and electronic media (including video, TV, and online components), which can be recognized as the major delivery components in the teaching-learning process and model [38]. So, OUSL students mostly preferred such printed and electronic materials for awareness programs. However, some OUSL science undergraduates (38\%) have perceived that their second choice is "Campaigns/ Activities of non-governmental organizations."

\subsection{Perceived Solutions for the Way of Improving Environmental Policy Implementation}

There are different approaches to enhancing the effectiveness of environmental management in Sri Lanka. Engineering (31.2\%), Science (32.6\%), and Arts/Social Sciences $(33.7 \%)$ of the UP and Science (39.2\%), Law (26.3\%), and Engineering $(24.5 \%)$ of OUSL reported "Broadening Environmental Education" as the most important approach (Table 6). Law undergraduates of the UP (33.3\%) perceived their first preference as "Strengthening policy implementation" and Management undergraduates of UP (25.8\%) perceived the priority as "Decentralizing economic decision-making." Management (31.7\%), Law (27.4\%), 
and Social Sciences (30\%) undergraduates of OUSL perceived the best approach as "Encouraging public participation." All respondents agreed that Public participation and awareness were the most effective approaches to conservation of nature.

Table 6. Factors mostly facilitate environmental policy implementation.

\begin{tabular}{cccccccc}
\hline University & Discipline & SPI & LHPP & BEE & DATF & EPP & DEDM \\
\hline & Engineering & 6.2 & 18.8 & 31.2 & 16.7 & 21.9 & 5.2 \\
Undergraduates of UP & Science & 13.7 & 14.7 & 32.6 & 24.2 & 12.6 & 2.1 \\
& Management & 19.4 & 9.7 & 12.9 & 19.4 & 12.9 & 25.8 \\
& Law & 33.3 & 8.3 & 8.3 & 16.7 & 16.7 & 16.7 \\
& Arts / Social Sciences & 12.7 & 13.9 & 33.7 & 10.2 & 12 & 17.5 \\
\hline \multirow{2}{*}{ Undergraduates of the OUSL } & Engineering & 5.7 & 16 & 24.5 & 17 & 17 & 19.8 \\
& Science & 1.3 & 13.9 & 39.2 & 22.8 & 21.5 & 1.3 \\
& Management & 6.7 & 15 & 18.3 & 20 & 31.7 & 8.3 \\
& Arts / Social Sciences & 16.7 & 16.7 & 18.3 & 15 & 30 & 3.3 \\
\hline
\end{tabular}

SPI-Strengthening policy implementation; LHPP_Levying heavy penalties on polluters; BEE-Broadening environmental education; DATF_-Developing advanced technology and facilities; EPP_Encouraging public participation; DEDM-Decentralizing economic decision-making.

\section{Discussion}

\subsection{Socioeconomic Background}

Recognition of a possible correlation between the socioeconomic status of undergraduates with environmental literacy level is important to a sustainable educational management process [39]. The results of this study revealed that the majority of students were below the 30-year age category in both conventional and ODL universities. However, employed and married students above this age threshold were registered for law and management disciplines of the OUSL, which can be attributed to the flexible and open distance teaching-learning process. In general, undergraduates at OUSL were from lower socioeconomic status than their counterparts in UP. Female dominated populations were indicated in both conventional and ODL universities of Sri Lanka. Most of the enrolled students sampled from both institutes were from very popular schools. Undergraduates of science and engineering in the conventional setup and humanities and social sciences disciplines of ODL are from higher socioeconomic backgrounds. Education is an important way for children in low-income families to change their social status [36,39].

\subsection{Interest in Environmental Related Activities}

Sri Lanka is a tropical island with diverse vegetation types of more than $29 \%$ of the forest cover, but gradually decreasing [40]. So, the physical environment of the country facilitates students to interact with the environment. The attitude, behavior, and mental setup of any person is molded by their primary school education experiences. Sri Lanka provides totally free school education (hence the literacy level was $91.71 \%$ in 2018 [41]) and the primary level school curriculum includes a considerable amount of experimental exploration activities [42]. The social culture of the country itself restricted young university students to engage in some leisure time activities (i.e., drinking in pubs) as available to western undergraduates. So, undergraduates have time to interact and feel interested in environmental activities at a comparatively higher level.

The environment-related activities have a strong relationship to the college's physical surroundings. For example, the UP being located in hill country areas facilitates hiking through the University Explorers' Club (UEC) of UP, the most active nature exploration society in Sri Lanka for engaging in nature exploration activities. Meanwhile, the OUSL is located in an urban environment, thus demanding tree planting or horticultural activities to provide green space to mitigate the heat island effect [43].

Gulgun et al. [9] have recognized that $56.4 \%$ of undergraduates are interested in any environmental activity. Uitto et al. [44] recognized that the student's interest in the environment was positively correlated with attitude. Then, attitude makes actions through positive 
behavior. Lavega [45] reported that the levels of knowledge and attitude differ when comparing activities for entertainment. Students who preferred outdoor activities showed higher scores of knowledge and environmental literacy level (Which was determined by a structured questionnaire) than those who preferred social activities. The study carried out by Lavega [45] recognized that of the two outdoor activities, individuals with higher environmental literacy showed higher interest in gardening than sports. So, the level of interest in the environment positively interacts with the literacy level of an individual. School students are more interested in activities that occur in nature. They are the direct participants and have a subjective feeling of really doing something to protect the environment [46]. Natural environments promote physical activity and are psychologically restorative. The best teaching-learning process is to facilitate the active interaction of the child with the natural environment. In adults, performing physical activities in nature provides additive benefits of self-esteem [47]. It is recommended to increase activity-based environmental awareness programs in the university curriculum to improve the literacy level of undergraduates.

\subsection{Major Source of Information for Environmental Knowledge}

Results of this study have confirmed the statement "environmental education should be started at nursery school" [9]. Similar results are shown in Misfud [24], which indicates that the primary sources of environmental information are school (56.2\%), books $(47.4 \%)$, and the internet (37.8\%). Asunta [48] detected that the main information sources of environmental issues for secondary pupils in Finland are mass media and science teachers. Similarly, Sadik and Sadik [49] found that the Internet and television are effective in environmental awareness for teacher candidates.

University students are just past the adolescence age and generally perceive knowledge in different sectors from their peer groups. So, the development of peer interactions to improve environmental literacy is essential to maintain the sustainability of knowledge. So, starting university societies related to the environment would help to increase communication with peers in the environment. A person's environmental behavior directly is highly influenced by his or her environmental knowledge level [50]. Hence, strengthening different sources of information are very important to ensure positive environmental attitudes and behavior.

\subsection{Diversity of Existing Environmental Knowledge among Different Disciplines}

A former study [51] on environmental knowledge, attitude, and behavior among university students highlighted that a "Lack of factual knowledge, incomplete understanding of global issues or perceptions of missing information may have led to the low number of correct responses", which were comparable with our results. In 2018, Lloyd-Strovas et al. [52] showed that undergraduates had somewhat high attitudes $(63 \%)$ but low levels of familiar knowledge (40\%), factual knowledge (56\%), and behavior ( $44 \%)$, and recommend infusing EE within university curricula to increase environmental literacy levels of students, who are future policymakers. The knowledge of the environment of undergraduates was $<40 \%(18.5-38 \%)$ in all disciplines. Hence, more attention needs to be paid to the Sri Lankan contest, especially for non-science-based disciplines.

\subsection{Comparison of Existing Level of Environmental Knowledge with Family Income}

In general, family income relates strongly to both brain structure and the nature to gain knowledge among the most disadvantaged children's groups [53]. Similarly, Tilikidou [54] found that environmental knowledge and income level positively correlated with the level of environmental knowledge in Greeks. Contreras [22] recognized that there were no significant differences in the environmental literacy of the respondents within the year level of study, or gender, age, residence location, nor the number of household members. However, Yilmaz et al. [55] recognized that students with high family income, and those students living in urban areas, displayed more positive attitudes toward environmental 
issues than did students with low family income, and those living in suburban areas. Family income fulfills the basic needs of any individual. According to Maslow's hierarchy of needs theory, without satisfying the basic needs of an individual, they may not be able to gather higher needs such as knowledge about the environment.

\subsection{Awareness of Environmental Problems and Its Effects}

Recognition of the level of knowledge on global issues at the university level is very useful to make future mitigation measures [4]. Students perceived that the media underestimated the loss of biological diversity and global warming [56]. Heat, drought and other water supply issues are increasing due to global warming, and these affect the community's health [16,57]. Wachholz et al. [58] have recognized that the majority of university students are concerned about climate change and recognize it as human-induced. However, Mun et al. [59] found that most university students maintain misconceptions about climate change and ozone layer depletion (OLD). Research has shown that high school and college students have a lack of conceptual understanding of OLD and other global issues $[60,61]$. Similarly, there are misconceptions and poor knowledge about OLD in preservice elementary science teachers [62]. Sung-Kyu [63] also recognized that the elementary school children have shown sufficient knowledge on the role of acid-based solutions in the laboratory, but not much awareness of the environmental effects of acid rain.

\subsection{The Attitude and Behavior of the Undergraduates towards the Environment}

It was found that there is a strong correlation between environmental literacy level and the attitude of individuals [64]. The attitude of someone would help to make eco-friendly environmental behaviors in the long run. It is implied that whether or not undergraduates positively behave to enhance environmental conservation themselves, they may not act on others' misbehavior. Raman [65] found that females and health discipline students have shown higher positive environmental attitudes and behaviors than male students of humanities and engineering. However, our studies have not recognized such discrepancies between disciplines or gender. Similarly, it is found that the environmental behavior of undergraduates of different countries varied with culture, environmental structures, services in each country, and knowledge [66]. Moreover, the attitude and behavior of university students can be positively improved with proper environmental education in a particular area [67].

\subsection{Perceived Responses to Most Viable Solutions, Attract Public Attention and Policy Implementation for Environmental Issues in Sri Lanka}

The perceived answers to item 27 of the questionnaire clearly showed that the students mostly found solutions related to their relevant field of study. For example, law students are mainly concerned with strengthening legislation to protect the environment. As a conclusive remark, it can be summarized that most of the undergraduates mainly believe in the change of the human mind toward the environment by education. That was a positive development for these future leaders in Sri Lanka. University students mostly selected (item 28) "TV-Radio" are the most effective activity to attract public attention to the environmental issues in Sri Lanka. These results were comparable with the study of Veisi et al. [25]. Finally, recommended policy implementation with help of broadening of EE and encouraging public participation by the majority of future policymakers is a positive sign of the future.

\subsection{Perceived Solutions for Environmental Issues in Sri Lanka}

The responses received from the open-ended part of the questionnaire, to educate people on the environment and its conservation, can be recognized as the most suitable solution for sustainable environment management in Sri Lanka. The second solution is the strengthening of legal procedures to minimize issues related to the environment. The third option was to solve the environmental issues due to agricultural activities in the country. The impact of people trying to perceive and interpret the relative health of 
environmental systems and taking appropriate actions to maintain, restore, or improve the health of those systems is very important. Therefore, environmental teaching and learning are very necessary and help to improve the environmental behaviors of the people [50]. Environmental issues and considerations have to a high extent become an integrated part of most laws and regulations. Many decision-makers and planners increasingly recognize implementing sustainable management approaches and promoting conservation efforts as the appropriate path [68]. Hence, perceived solutions by future policymakers in the country are important to improve environmental policy implementation.

\section{Conclusions}

The aim of this study was to explore undergraduate perceptions of major environmental issues on a global scale. The majority of university students (94\%) are engaged in environmental-related activities. School education was recognized as a major source of information about environmental awareness, i.e., UP (37.7\%) and OUSL (40.5\%) hence recommended providing the environmental concepts from primary school levels. This study found that peer discussions on the environment were lacking amongst undergraduates.

Significant differences were found in the environmental literacy level of the respondents according to the course discipline, family income, and the educational background of the family. However, no such differences are recognized between ODL and conventional learners. It would be due to gaining literacy of the environment mainly in the school setup. The existing knowledge level on the environment was less than $40 \%$ for all the study samples. Hence, we recommend strengthening the environment-related courses in the formal school curriculum as well as at the university level, with special attention paid to the socioeconomically oppressed and vulnerable students.

Both undergraduate groups (52.2\% of UP and $41.2 \%$ of OUSL) have identified global warming as the major environmental issue in the world. This could be due to electronics and printed media keeping global warming as the first priority. It is recognized that both undergraduate groups showed a satisfactory level of environmental attitude and behavior, but necessary openings must be made for undergraduates to actively engage in environmentrelated activities. Undergraduates recognized that the use of TV-Radio is the most effective medium for public awareness of environmental issues. However, few of them utilized said media to gain information on the environment. University students were knowledgeable about electronic online media and educational technologies. Improving awareness in students through mobile and web-learning would be highly effective for future generations. Undergraduates of both institutions repeated on several occasions that the "Expansion of Environmental Education" is the most important approach to sustainable management and protecting the environment. The study revealed that school education is the main source of environmental awareness and the university sector is not highlighted. In addition, undergraduates believed that political intervention seems to be an obstacle to solve environmental issues, especially in Sri Lanka. Finally, the study recommends that future investigations should be formulated with diverse social strata to see the overall picture.

Supplementary Materials: The following are available online at https:/ / www.mdpi.com/2071-105 0/13/3/1056/s1, Figure S1. Questionnaire from the student opinion survey concerning environment literacy on issues, local/international agreements, attitudes, behavior, and policies. The wording of the questions was formulated using predefined scales of answers (source: authors' research).

Author Contributions: Conceptualization, supervision, and writing-analysis, review, and editing, J.K.; writing - analysis, review, and editing, V.S. and B.M. All authors have read and agreed to the published version of the manuscript.

Funding: This research received no external funding.

Institutional Review Board Statement: The proposal of this study approved by the centre for the partial fulfillments of Environmental Studies and Sustainable Development, The Open University of Sri Lanka, Nugegoda for the Masters of Environmental Science degree programme. 
Informed Consent Statement: University students volunteered to do the survey.

Data Availability Statement: Data sharing not applicable.

Acknowledgments: We would like to thank Karley Rojas for proofreading the article and three anonymous reviewers for their constructive comments.

Conflicts of Interest: The authors declare no conflict of interest.

\section{References}

1. Meia, N.S.; Waia, C.W.; Ahamadb, R. Environmental Awareness and Behavior Index for Malaysia, Procedia. Soc. Behav. Sci. 2016, 222, 668-675. [CrossRef]

2. IPCC. Climate Change 2001: The Scientific Basis. Contribution of Working Group I to the Third Assessment Report of the Intergovernmental Panel on Climate Change, Report; IPCC: Geneva, Switzerland, 2001.

3. Beníteza, P.C.; McCallum, I.; Obersteiner, M.; Yamagata, Y. Global potential for carbon sequestration: Geographical distribution, country risk and policy implications. Ecol. Econ. 2007, 60, 572-583. [CrossRef]

4. Wong, K. The environmental awareness of university students in Beijing, China. J. Contemp. China 2003, 12, 519-536. [CrossRef]

5. EPA. What Is Environmental Education? United States Environmental Protection Agency: Washington, DC, USA, 2020. Available online: https:/ / www.epa.gov/education/what-environmental-education (accessed on 21 October 2020).

6. NAAEE. What Is Environmental Education? North American Association for Environmental Education: Washington, DC, USA; Available online: https:/ / naaee.org/about-us/about-ee-and-why-it-matters (accessed on 11 April 2020).

7. Hougham, J.; Kerlin, S.; Liddicoat, K.; Ellis, K.; Crampe, E. Status and Needs of Environmental Education Related Organizations in Wisconsin: Results from the 2015 State-Wide Survey. Madison, Wisconsin. 2017. Available online: https://www.researchgate.net/publication/318405514_Status_and_Needs_of_Environmental_Education_Related_Organizations_ in_Wisconsin_Results_from_the_2015-2016_state-wide_survey (accessed on 21 October 2020).

8. Meredith, J. Best Practices for Environmental Education: A Strategic Plan for Environmental Education; Ohio Environmental Education Council of Ohio: Akron, OH, USA, 2000; pp. 1-65.

9. Gulgun, B.; Onder, S.; Aktas, E.; Ankaya, F.U. Responses of university students related to environmental problems: A case study of Ege University (Izmir-Turkey). J. Int. Environ. Appl. Sci. 2008, 3, 234-246.

10. Selvam, V.; Nazar, N.A. An analysis of environmental awareness and responsibilities among university students. Int. J. Curr. Res. 2011, 3, 202-205.

11. Liu, S.; Lin, H. Undergraduate students' ideas about nature and human-nature relationships: An empirical analysis of environmental worldviews. Environ. Educ. Res. 2014, 20, 412-429. [CrossRef]

12. Yazici, N.; Babalik, A.A. Determination of environmental awareness of university students: The case of Suleyman Demirel University (SDU). Environ. Earth. Sci. 2016, 75, 190. [CrossRef]

13. Övsün, A.; Gündüz, S.. The Study of University Students' Awareness and Attitude towards Environmental Education in Northern Cyprus. EURASIA J. Math. Sci. Technol. Educ. 2018, 14, 1057-1062.

14. Han, Z.; Wang, Q.; Yan, X. How responsible leadership motivates employees to engage in organizational citizenship behavior for the environment: A Double-Mediation Model. Sustainability 2019, 11, 605. [CrossRef]

15. Madurapperuma, B.D.; Kuruppuarachchi, K.A.J.M.; Amarasinghe, J.; Walpola, T.K. Radical learning in arboriculture: Environmental education on biodiversity and forest restoration via exploring a nature tour at the IFS-Popham Arboretum in Sri Lanka. In Proceedings of the International Symposium 2015 Environment Management and Planning, Battaramulla, Sri Lanka, 23-24 February 2015; Center Environment of Sri Lanka: Colombo, Sri Lanka, 2015; Volume 1, p. 39.

16. Ullah, M.O.; Hasan, M.A.; Uddin, T. Environmental awareness and behavior towards the environment of the students with environmental disasters factors in private universities in Sylhet, Bangladesh. J. Appl. Quant. Methods 2013, 8, 34-42.

17. Afzaad, A.; Israr, A. Environment friendly products: Factors that influence the green purchase intentions of Pakistani consumers. Pak. J. Eng. Technol. Sci. 2012, 2, 84-117.

18. Ahu, E.; Banris, G.B.; Seda, G.T. Effect of materialism and environmental knowledge on environmental consciousness among high school students: A study conducted in Istanbul province. Int. J. Hum. Sci. 2015, 12, 511-526.

19. Leong, M.C.F.; Ho, J.C.; Lee, P.C.T.; Hokama, T. Risk perception of nuclear power plants among university students in northeast Asia after the Fukushima nuclear disaster. Asia-Pac. J. Public Health 2014, 26, 631-641.

20. Nigatu, A.S.; Asamoah, B.O.; Kloos, H. Knowledge and perceptions about the health impact of climate change among health sciences students in Ethiopia: Across-sectional study. BMC Public Health 2014, 14, 587. [CrossRef]

21. Abbas, M.Y.; Singh, R. A survey of experimental awareness, attitude and participation amongst university students: A case study. Int. J. Sci. Res 2014, 2319-7064, ISSN 2319-7064.

22. Contreras, R.C.C. Assessment of environmental literacy, concern and disaster preparedness among college students. Asia Pac. J. Multidis. Res. 2014, 2, 1-11.

23. Aminrad, Z.; Azizi, M.; Wahab, M.; Huron, R.; Nawawi, M. Environmental Awareness and attitude among Iranian students in Malaysian universities. Environ. Asia 2010, 3, 1-10.

24. Misfud, M.C. An Investigation on the Environmental Knowledge, Attitudes and Behavior of Maltese Youth. US-China Educ. Rev. 2011, B3, 413-422. 
25. Veisi, H.; Lacy, M.; Mafakheri, S.; Razaghi, F. Assessing environmental literacy of university students: A case study of Shahid Beheshti University in Iran. Appl. Environ. Educ. Commun. 2018, 18, 25-42. [CrossRef]

26. Teksoz, G.; Sahin, E.; Tekkaya-Oztekin, C. Modeling Environmental Literacy of University Students. J. Sci. Educ. Technol. 2011, 21, 157-166. [CrossRef]

27. Shephard, K.; Harraway, J.; Lovelock, B.; Skeaff, S.; Slooten, L.; Strack, M. Is the environmental literacy of university students measurable? Environ. Educ. Res. 2014, 20, 476-495. [CrossRef]

28. Chen, C.; Tsai, C. Marine environmental awareness among university students in Taiwan: A potential signal for sustainability of the oceans. Environ. Educ. Res. 2016, 22, 958-977. Available online: http://www.tandfonline.com/loi/ceer20 (accessed on 7 January 2020). [CrossRef]

29. De Carvalho Maffia, A.M.; Silva, E.; Jacovine, L.A.G. Environment and environmental awareness: How university students conceive and act. Acta Scientiarum. Biol. Sci. 2011, 2, 209-214.

30. Sachitra, K.M.V.; Kaluarachchi, D.G.P. Educating for Environmental Practices: An Assessment from Bachelor of Commerce (B. Com) Undergraduates in Sri Lankan State Universities; VJM Univ. Sri Jayewardenepura: Nugegoda, Sri Lanka, 2018; Volume 4, pp. $27-49$.

31. Zsóka, Á.; Szerényi, Z.M.; Széchy, A.; Kocsis, T. Greening due to environmental education? Environmental knowledge, attitudes, consumer behavior and everyday pro-environmental activities of Hungarian high school and university students. J. Clean. Prod. 2013, 48, 126-138.

32. Undergraduate Guidebook Faculty of Natural Sciences; The Open University of Sri Lanka: Nugegoda, Sri Lanka, 2020; pp. 1-3.

33. Annual Report-University of Peradeniya.; University of Peradeniya: Peradeniya, Sri Lanka, 2018; pp. 1-221.

34. American Association for Public Opinion Research. Standard Definitions: Final Dispositions of Case Codes and Outcome Rates for Surveys, 2nd ed.; AAPOR: Washington, DC, USA, 2000.

35. Sahin, E.; Alper, U.; Oztekin, C. Modelling pre-service science teachers' pro-environmental behaviours in relation to psychological and cognitive variables. Environ. Educ. Res. 2020, 1-21. [CrossRef]

36. Kuruppuarachchi, K.A.J.M.; Sayakkarage, V. Comparison of socio-economic status of undergraduates in the conventional and ODL's universities. In Proceedings of the International Conference on Open and Innovative Education (ICOIE 2020), Kowloon, Hongkong, 2-4 July 2020; The Open University of Hong Kong: Kowloon, Hong Kong, 2020; pp. 177-192.

37. Ozsoy, S.; Ertepiner, H.; Saglam, N. Can eco-schools improve elementary school students' environmental literacy levels? Asia-Pac. Forum Sci. Learn. Teach. 2012, 13, 1-25.

38. Bozkurt, A. From Distance Education to Open and Distance Learning: A Holistic Evaluation of History, Definitions, and Theories. In Handbook of Research on Learning in the Age of Transhumanism; Sisman-Ugur, S., Kurubacak, G., Eds.; IGI Global: Hershey, PA, USA, 2019; pp. 252-273. [CrossRef]

39. Han, I.V. The effects of family income on children's education: An empirical analysis of CHNS data. Res. Mod. High. Educ. 2017, 4, 49-54.

40. Ranagalage, M.; Gunarathna, M.H.J.P.; Surasinghe, T.D.; Dissanayake, D.; Simwanda, M.; Murayama, Y.; Morimoto, T.; Phiri, D.; Nyirenda, V.R.; Premakantha, K.T.; et al. Multi-Decadal Forest-Cover Dynamics in the Tropical Realm: Past Trends and Policy Insights for Forest Conservation in Dry Zone of Sri Lanka. Forest 2020, 11, 836. [CrossRef]

41. World Bank. Sri Lanka Literacy Rate 1981-2020. Available online: https://www.macrotrends.net/countries/LKA/sri-lanka/ literacy-rate\# (accessed on 25 December 2020).

42. School Syllabus and Teacher Instruction Guide, Sri Lanka, National Institute of Education, Sri Lanka. Available online: https: / / www.edulanka.lk/syllabus (accessed on 25 December 2020).

43. Madurapperuma, B.D.; Kuruppuarachchi, K.A.J.M. Rehabilitating a landfill site of lowland tropical landscape into an urban green space: A case study from the Open University of Sri Lanka. Int. J Sustain. Built Environ. 2016, 5, 400-410. [CrossRef]

44. Uitto, A.; Juuti, K.; Lavonen, J.; Byman, R.; Meisalo, V. Secondary school students' interests, attitudes and values concerning school science related to environmental issues in Finland. Environ. Educ. Res. 2011, 17, 167-186. [CrossRef]

45. Lavega, D.L.E. Awareness, Knowledge, and Attitude about Environmental Education: Responses from Environmental Specialists, High School Instructors, Students and Parents. 2004. Available online: http:/ / etd.fcla.edu/CF/CFE0000207/LassodelaVega_ Ernesto_R_200412_EdD.pdf (accessed on 1 November 2019).

46. Veselinovska, S.S.; Osogovska, T.L. Engagement of students in environmental activities in school. Procedia. Soc. Behav. Sci. 2012, 46, 5015-5020. [CrossRef]

47. Wood, C.; Sandercock, G.; Barton, J. Interactions between physical activity and the environment to improve adolescent self-esteem: A randomised controlled trial. Int. J. Environ. Health 2014, 7, 144-155. [CrossRef]

48. Asunta, T. Knowledge of Environmental Issues. Where Pupils Acquire Information and How It Affects Their Attitudes, Opinions, and Laboratory Behaviour; University of Jyväskylä: Jyväskylä, Finland, 2003; p. 159.

49. Sadik, F.; Sadik, S. A study on environmental knowledge and attitudes of teacher candidates. Procedia. Soc. Behav. Sci. 2013, 116, 2379-2385. [CrossRef]

50. Zareie, B.; Navimipour, N.J. The impact of electronic environmental knowledge on the environmental behaviors of people. Comput. Hum. Behav. 2016, 59, 1-8. [CrossRef]

51. He, X.; Hong, T.; Liu, L.; Tiefenbacher, J.A. Comparative study of environmental knowledge, attitudes and behaviors among university students in China. Int. Res. Geogr. Environ. Educ. 2011, 20, 91-104. [CrossRef] 
52. Lloyd-Strovas, J.; Moseley, C.; Arsuffi, T. Environmental Literacy of Undergraduate College Students: Development of the Environmental Literacy Instrument (ELI); School Science and Mathematics, John Wiley \& Sons, Inc.: Hoboken, NJ, USA, 2018; Volume 118, pp. 84-92.

53. Noble, K.G.; Houston, S.M. Family income, parental education and brain structure in children and adolescents. Nat. Neurosci. 2015, 18, 773-778. [CrossRef]

54. Tilikidou, I. The Effects of Knowledge and Attitudes upon Greeks' Pro-Environmental Purchasing Behavior, Corporate Social Responsibility and Environmental Management; Wiley Inter Science: Hoboken, NJ, USA, 2007; Volume 14, pp. 121-134.

55. Yilmaz, O.; Boone, W.J.; Andersen, H.O. Views of elementary and middle school Turkish students toward environmental issues. Int. J. Sci. Educ. 2004, 26, 1527-1546. [CrossRef]

56. Keinonen, T.; Palmberg, I.; Kukkonen, J.; Yli-Panula, E.; Persson, C.; Vilkonis, R. Higher Education Students' Perceptions of Environmental Issues and Media Coverage. Discourse Commun. Sustain. Educ. 2016, 7, 5-22. [CrossRef]

57. Singh, R.L.; Singh, P.K. Global Environmental Problems. In Principles and Applications of Environmental Biotechnology for a Sustainable Future. Applied Environmental Science and Engineering for a Sustainable Future; Singh, R., Ed.; Springer: Singapore, 2017; p. 12. [CrossRef]

58. Wachholz, S.; Artz, N.; Chene, D. Warming to the idea: University students' knowledge and attitudes about climate change. Int. J. Sustain. High. Educ. 2014, 15, 128-141. [CrossRef]

59. Mun, K.; Kim, J.; Kim, S.; Krajcik, J. Exploration of High School Students' Concepts About Climate Change Through the Use of an Issue Concept Map (IC-Map). In International Conference on Science Education 2012 Proceedings; Springer: Berlin/Heidelberg, Germany, 2012; pp. 209-222.

60. Leighton, J.P.; Bisanz, G.L. Children's and adults' knowledge and models of reasoning about the ozone layer and its depletion. Int. J. Sci. Educ. 2003, 25, 117-139. [CrossRef]

61. Howard, K.E.; Brown, S.A.; Chung, S.H.; Jobson, B.T.; VanReke, T.M. College students' understanding of atmospheric ozone formation. Chem. Educ. Res. Pract. 2013, 14, 51-61. [CrossRef]

62. Çeliklera, D.; Aksanb, Z. Determination of pre-service elementary science teachers 'knowledge level about $t$ ozone layer. Procedia Soc. Behav. Sci. 2011, 15, 1438-1444. [CrossRef]

63. Sung-Kyu, K.I.M. An Understanding of Elementary School Students on the Acid-Base, Acid Rain and Soil Acidification. J. Fish. Marin. Sci. Educ. 2015, 27, 1764-1782.

64. Iwaniec, J.; Curdt-Christiansen, X.L. Parents as Agents: Engaging Children in Environmental Literacy in China. Sustainability 2020, 12, 6605. [CrossRef]

65. Raman, R.A. Attitudes and behaviour of Ajman University of science and technology students towards the environment. IAFOR J. Educ. 2016, 4, 69-88. [CrossRef]

66. Vicente-Molina, M.A.; Fernández-Sáinz, A.; Izagirre-Olaizola, J. Environmental knowledge and other variables affecting proenvironmental behaviour: Comparison of university students from emerging and advanced countries. J. Clean. Prod. 2013, 61, 130-138. [CrossRef]

67. Ibáñez, M.E.; Ferrer, D.M.; Muñoz, L.V.A.; Claros, F.M.; Ruiz, F.J.O. University as Change Manager of Attitudes towards Environment (The Importance of Environmental Education). Sustainability 2020, 12, 4568. [CrossRef]

68. Kallesoe, M.; De Alvis, D. Review of Developments of Environmental Services Markets in Sri Lanka; IUCN; World Agroforestry Centre (ICRAF), Southeast Asia Regional Office: Bogor, Indonesia, 2004. 